\title{
CONCEPT, ESSENCE AND TYPES OF ADMINISTRATIVE-LEGAL RELATIONS IN THE SPHERE OFANATOMICAL MATERIALS' TRANSPLANTATION
}

\section{ПОНЯТТЯ, СУТНІСТЬ ТА ВИДИ АДМІНІСТРАТИВНО-ПРАВОВИХ ВІДНОСИН У СФЕРІ ТРАНСПЛАНТАЦІЇ АНАТОМІЧНИХ МАТЕРІАЛІВ ЛЮДИНІ}

\author{
Novytska M.M., Advocate, \\ Postgraduate Student of the Department of Administrative, \\ Commercial Law and Financial and Economic Security \\ of the Educational and Scientific Institute of Law of Sumy State University
}

\begin{abstract}
Over the past fifty years, organ transplantation has become a common practice of a worldwide nature, which brings tremendous benefits to hundreds of thousands of patients. The use of human organs for their subsequent transplantation has been steadily increasing over the past two decades. Organ transplantation is the most cost-effective method for treating kidney failure at its final stage. At the same time, it is the only current treatment of renal, pulmonary and heart failure in their final stages.

In connection with the marked increase in recent years in the practice of treating patients through the transplantation or transplantation of seized human cells, tissues or other materials, most states, including Ukraine, felt the need for a new and more specific legislation.

Transplantology is a division of medicine that studies organ and tissue transplantation, as well as a branch of medical practice, which consists in the practical realization of operations for the seizure and further transplantation of anatomical material. When transplanting an organ or tissue, there are a number of issues that require resolution: the volume of personal rights and freedoms of the recipient and the donor, their guarantees; legal regulation of medical manipulations; moral and ethical issues; like that. Therefore, this most complex type of medical intervention needs
\end{abstract} most of all normative detail and legal consolidation.

Key words: transplantation, organ transplantation, anatomical materials, relations in field of transplantation of anatomical materials.

За останні п'ятдесят років трансплантація органів стала звичайною практикою всесвітнього характеру, яка приносить величезну користь сотням тисяч пацієнтів. Використання людських органів для їх подальшої трансплантації послідовно збільшувалося за останні два десятиліття. Трансплантація органів являє собою найбільш рентабельний метод лікування ниркової недостатності на ії завершальній стадії. Водночас вона єдиний на даний час спосіб лікування ниркової, легеневої і серцевої недостатності на їхній завершальній стадії.

У зв'язку з помітним зростанням останніми роками практики лікування пацієнтів шляхом трансплантації чи пересадки вилучених людських клітин, тканин або інших матеріалів, більшість держав, зокрема і Україна, відчули необхідність у створенні нового і більш специфічного законодавства.

Трансплантологія є розділом медицини, що вивчає трансплантацію органів і тканин, а такожє галуззю медичної практики, що полягає у практичному виконанні операцій із вилучення та подальшої пересадки анатомічного матеріалу. Під час пересадки органа чи тканини постає ціла низка питань, які потребують вирішення: обсяг особистих прав і свобод реципієнта та донора, їхні гарантії; правове регулювання медичних маніпуляцій; моральні й етичні питання тощо. Тому цей надскладний вид медичного втручання чи не найбільше потребує нормативної деталізації та правового закріплення. ріалів.

Ключові слова: трансплантація, трансплантація органів, анатомічні матеріали, відносини у сфері трансплантації анатомічних мате-

The relevance of the topic is associated with the urgent need to reform the field of organ transplantation. Currently, this area of medicine is of paramount importance, since it is the only chance to save a person with certain diseases. The state must make great efforts to move the transplant from the point of stagnation where it is now. The shortcomings of administrative and legal regulation, the incorrect and incomplete implementation of the law create enormous difficulties for the effective and full functioning of transplantology, and sometimes even make its existence impossible. One of the issues that need to be addressed in the near future is the definition of the concept of transplantation and the scope of regulation of this issue.

An analysis of recent research and publications indicates that a large number of scientists in their work emphasized the need for the earliest possible reform of the legislation on transplantology, namely: V. Glushkov, S. Grinchak, D. Kobyakov, N. Margatskaya, I. Mishchuk, O. Pelagesha, S. Tikhonov, B. Todurov, V. Shumakov etc. On the basis of this, it is necessary to single out the most significant points concerning the essence of the problem being studied.

The purpose of the article is to determine the significance of the concept of transplantation, its main meaning and essence, and also the main types of anatomical transplantation should be highlighted on the basis of the relationships that have emerged today.

Essential material. The term transplantation comes from the latin. "transplantare" - to replace and greek. "logos" knowledge, teaching. The essence of this method is to trans- plant an organ or tissue (graft) taken from a donor to the recipient, or it may consist in the transplantation of cloned tissues or artificial implants (electronic, metal, etc.), which is carried out (most often) by surgical intervention.

According to the large medical encyclopedia, under transplantology it is necessary to understand the branch of biology and medicine that studies the problems of transplantation and develops methods for preserving organs and tissues, the possibility of creating and using artificial organs [1, p. 142].

By definition, the World Health Organization, transplantation is the transfer of living or dead tissue or organ between persons of the same or different species [2]. Organs or tissues that are used for transplantation can be taken from both a donor-corpse and a live donor. According to Article 1 of the Law of Ukraine "On Transplantation of Organs and Other Anatomical Materials of a Person" dated July 16, 1999. Transplantation is a special treatment method consisting in transplanting a recipient of an organ or other anatomical material taken from a person or an animal [3]. And according to the new law "On the Application of Transplantation of Anatomical Materials to Man" dated May 17, 2018, transplantation should be understood as a special treatment method consisting in transplanting human anatomical material from a donor to a recipient and is aimed at restoring human health [4].

The Additional Protocol to the Convention on Human Rights and Biomedicine regarding the transplantation of human organs and tissues defines the term "transplantation" as the complete process of removing an organ or tissue from one person and implanting this organ or tissue to another per- 
son, including all procedures for preparation, preservation and storage [5].

In our opinion, transplantation should be understood as a system of medical manipulations for the extraction and transfer of biological material from a donor to a recipient in their viable state and the further implementation of diagnostic, measures and therapeutic manipulations for their normal functioning.

The special nature of the legal regulation of transplantation is brought about by the fact that an organ or tissue transplant operation concerns two people at the same time: the donor and the recipient, this method of treatment differs from others, and the usual "doctor - patient" treatment process in the field of transplantation looks like "donor - recipient - doctor". This fact determines the existence of the point of view that transplantation is closest to the legal science of all medical disciplines; therefore, therefore, it needs more precise legal regulation [6, p. 98].

Today in the legal literature there is no single point of view on the nature of the relationship arising from the transplantation of anatomical materials. The thoughts of scientists divided into several camps. Currently, there is no unambiguous decision on their regulation by a specific branch of law.

The question of transplantology in the prism of criminal law was dealt with by such scientists as S. Hrinchak, A. Musienko, G. Chobotareva, etc. They carried out a thorough work to determine the extent of public relations in the field of transplantation covered by criminal law. In particular the composition of the crimes of Articles 142-144 of the Criminal Code of Ukraine (concerning responsibility for the illegal conduct of experiments on a person, violation of the procedure for the transplantation of organs or tissues of a person established by law, violent donation), grounds and procedure for imposing liability [7]. Proceeding from the legal relationship regulating this branch of law, it should be noted that its norms are aimed primarily at the protection of transplantation relations, the prevention of the commission of crimes in this area and the imposition of penalties in case of violation.

Equally important are the achievements in constitutional law, which include the constitutional rights and freedoms of each citizen fixed at the level of the Basic Law of the country, regardless of race, color, political, religious or other convictions, sex, ethnic and social origin, property status, place of residence, language and religion. Given the provisions of the Constitution of Ukraine, we can conclude that the protection of the rights of citizens in the field of transplantation of anatomical materials is the responsibility of the state and plays a prominent role in the system of realization of citizenship of their constitutional rights, since: 1) it is connected with the provision of the right to life; 2) constitutional rights and freedoms are aimed at ensuring the protection of the physical integrity of a person (potential donor / recipient) both in life and after death. The Constitution establishes that every person has an inalienable right to life (Article 27), freedom and personal integrity (Article 29), in particular in the exercise of his right to medical interference or prohibition of its implementation, health care, medical insurance and medical assistance (Article 49). The basic law declares the basic principles and provisions that can both be given to a certain range of rights (Article 28), and to restrict their implementation, in particular, the disposal of their own body (Article 64) [8].

Some part of the legal relationship in the field of transplantation of anatomical materials is in the area of financial law. It regulates relationships related to material security, funding and sponsorship in this area.

The field of labor law covers the relationship of medical personnel with health care establishments licensed to conduct economic activities in medical practice, which provides for the right to provide medical care through the use of transplantation and / or transplant related activities.

Some researchers believe that transplantation relations are civil-lawful. So, according to M. Bryukhovetska legal relation- ship of transplantation and donation has a number of civil-law features:

legal equality of the parties. The parties are independent of each other, endowed with a separate set of rights and responsibilities, have no dependence on each other. All subjects of legal relationship (donor, relatives, health care institution and recipient) have equal opportunities in realizing their rights.In this case, one cannot agree with the author, but it should be cited as a counterargument to M. Maleinawords, who points out that the administration of the health care institution has the power of authority and implements it in relation to its employees $[9$, p. 88];

free expression of the parties. Characterized in the given person's right to be a donor of organs or tissues or to refuse at will from it. No person can be compelled to do so against his will;

dispositive. Determines the ability of the parties to establish the nature and nature of their relationship within the limits permitted by law;

- a special nature of the connection between actors;

$[10$, p. 71$]$

the special nature of the protection of violated rights

However, in our opinion, this position is not sufficiently reasoned. Like most researchers, we are inclined to believe that relations in a series of transplantation of anatomical materials to a person are of an administrative and legal nature.

One of the representatives of this position is A. Pelagesha, who claims that the field of transplantation is subject to administrative and legal regulation, because:

"a) is a set of social relations arising from the need to perform a transplant;

b) within the framework of transplantation there are public relations that can be regulated by law;

c) covers the most important social relations arising at this moment to the greatest extent affect the interests of society and individual citizens. For society it is said about the need to ensure the possibility of transplantation in cases where other methods of treatment of a patient are unpromising. For an individual patient, of course, this becomes a matter of life in general" [11, p. 7]

I. Mishchuk in support of his position cites a number of principles in the field of transplantation, which characterize the presence of an authoritative character of legal relations

"1) the taking of organs can be carried out by medical institutions established by the ministries of health, which guarantee that the resuscitation of a potential donor and the statement of death, including the so-called cerebral, will correspond to the highest professional level and be carried out with the maximum degree of responsibility;

2) the team is a doctor of the alleged donor and establishes (ascertains) death, must be isolated from the transplant team (these are completely different medical teams);

3 ) the moment of death is determined by the commission, headed by the head of the intensive care unit and which includes several specialists selected in advance for this purpose" $[12$, p. 8$]$

In our opinion, the relations studied in the field of transplantation of anatomical materials are of an administrative and legal nature.

The sphere of transplantology, like any other type of public relations, requires legal regulation. So, the main factors influencing the need to regulate this sphere can be divided into two categories:

- factors that have already been formed, they include moral and ethical, medical and legal, such as a statement of brain death, the duration of artificial support for human life, the intensity and duration of resuscitation measures, decisions to turn off life support equipment, permission to collect organs, etc.;

- factors that have arisen recently, they include the exclusion of the human factor in the distribution of organs between 
recipients, forecasting risks for related donors, determining the legal status of organs and tissues after separation from the donor's organism, the legitimacy of using donations of living people, the danger of criminalization of transplantation, the moral aspect of transplantation xenografts, use of cells remote from human embryos.

In essence, administrative and legal relations in the field of transplantation of anatomical materials to a person are organizational relationships, because they are the expression of the boundaries within which the organizational impact of government entities on the relevant objects of the transplant sphere occurs. So, an example is the function of the central executive body that implements the state policy in the field of providing medical care with the use of transplantation and carrying out activities related to transplantation in the search and distribution of anatomical materials for a donor-recipient joint, as well as the search and acquisition of a sample of hematopoietic stem cells for a joint donor-recipient pair in Ukraine and abroad (Article 9) [4].

A systematic analysis of the legislation of our country gives reason to distribute administrative and legal relations in the field of transplantation of anatomical materials in several varieties.

Among legal scholars at the present time, there is no unified approach to the delimitation of transplant relations by type.

In particular, G. Anikina identifies transplant relations in the area of:

1) autotransplantation - consists in the procedure of transplanting its own anatomical material within one organism (for example, skin grafting from one part of the body to another in cases of burns or using parts of its own tissues, bones for plastic surgery);

2) isotransplantation (hemodialysis) - a combination of medical procedures for the transfer of anatomical material between genetically close organisms (for example, the transfer of organs or tissues between identical twins);

3) allotransplantation (heterologous) - the relationship associated with the transfer of anatomical material between organisms belonging to one species, however, differ genetically and immunologically;

4) xenotransplantation - associated with the transplantation of anatomical materials of animal origin (for example, using the valves of the heart of pigs);

5) transplantation of fetal materials and the taking of anatomical materials from the dead person $[13$, p. 7]. The above classification can be conditionally called "systematization of various types of grafts".

The scope of the law is somewhat at odds with this classification, as defined in Article 3, that relations in the field of transplantation include: transplantation of anatomical materials to humans; carrying out other activities related to transplantation; obtaining anatomical materials for the manufacture of bioimplants; xenotransplantation.

The following are not included in the circle of legal relations: donation of blood and its components and activities related to their use; transplantation of reproductive cells, gonads, living embryos; autotransplantation; implantation; sampling of anatomical materials for scientific and diagnostic studies; activity of cord blood banks, tissues and human cells.

When systematizing the approaches of various scholars to the question of systematization of these legal relations, the following distinction criteria can be distinguished:

1. By the subject composition of donors and recipients:

- the subject is an adult;

the subject is a person who, in accordance with the procedure established by law, is recognized to be partially capable;

- subject aged 14 years (minor);

the subject is a person recognized to be legally incapable under the procedure established by law;
- the subject is under the age of 14 (minor face).

2. By the type of objects:

- transplantation of regenerative objects (bone marrow);

- transplantation of non-regenerative objects (even -

lungs, kidneys, single - liver, heart);

3. By the type of donor:

- transplant "ex mortuo"- a transplant is taken from a deceased person (a donor-corpse);

- transplant "ex vivo" - a transplant is withdrawn from a living donor:

- family donation (from close relatives, family members); - cross-donation.

4. By the type of transplant:

- extraction and transplantation of organs (or organ com-

plexes: heart-lung);

- extraction and grafts;

- extraction and transfer of cell cultures.

The Law of Ukraine "On the Application of Transplantation of Anatomical Materials to Man" (Article 13) establishes a separate procedure for the application of transplantation of anatomical materials for various subjects.

For the implementation of transplant relations in relation to persons under the age of 14 (minors) or recognized in the prescribed manner as partially capable, the law requires the consent of the subjects themselves, not their relatives or representatives.

For persons recognized to be incapacitated, the inclusion of a psychiatrist in the consultation of doctors is also required in order to make a decision on the use of transplantation as an exclusive treatment for the patient.

In a separate category should be allocated to persons in emergency condition, that is, there is a direct and inevitable threat of death. In this case, the provision of medical care is carried out without the consent of the recipient, his parents or persons representing him.

In case of a categorical refusal of the recipient to apply a transplant to him, despite explanations of the attending physician about real serious consequences for him in case of refusal, the recipient must submit a written statement on refusal to provide him with medical care through transplantation.

In case of refusal of parents (legal representatives), whose consent is required for transplantation to the recipient, when there are real chances of serious consequences for the recipient, the head of the health facility should immediately contact the guardianship authorities. The guardianship authorities, within 24 hours from the moment of application of the head of the health care institution, decide on the provision of consent / disagreement on the operation.

The issue of legal relations in the field of child donation (minors and minors) is not clearly regulated in the legislation of Ukraine. Transplantation of a child from an adult can be performed as a general rule from a donor-corpse or from a related donor. However, there are certain features, since a kidney or part of the liver can be transplanted to a child from an adult, but the heart, lungs, trachea cannot be transplanted. The issue of ascertaining the death of a child is also not clearly settled, it is possible in this case to use the general rule established in the Order of the Ministry of Health "On the establishment of diagnostic criteria for brain death and the procedure for ascertaining the moment of death of a person" [14]. In some countries, children may be donors, for example, in Japan, where it has been permitted since 2009 or in the United States. In the Russian Federation, a bill was introduced that also allows child donation.

Conclusion. In different countries, the donation of such subjects is determined unequally. So, in Greece and Turkey it is allowed, and in Poland and Germany is prohibited. Legal relations with such a subject require additional regulatory and detailing to protect and respect the rights of this category of persons.

In legal relationships where the donor is a living person - a close relative or family member of the recipient (family donation), the decision on the admissibility of transplantation is 
made by a council of doctors based on the results of tests of the donor-recipient for immunological compatibility.

However, in practice this is not at all the case, since doctors, fearing criminal responsibility for violating the procedure for transplantation, refuse to carry out transplantation without a fact confirmed by a court of kinship.

There are cases when the recipient has a forum of an immunologically compatible related donor, then a consultation of doctors makes a decision on the use of cross-donation. Recipients who claim to apply a cross-donation procedure to them must be included in the Unified State Transplant System. The procedure for applying this type of donation should be regulated by the Cabinet of Ministers of Ukraine, but at present there is no such by-law. This means that the implementation of cross-donation is frozen and cannot be implemented.

The scientific and practical significance of the classification carried out by the types of administrative and legal relations in the field of transplantation allows unifying and streamlining these legal relationships. In addition, such systematization allows not only to effectively and thoroughly carry out improvements in the field of transplantation of anatomical materials, taking into account the peculiarities and differences of such legal relations, but also to carry out its legal regulation in different ways.

\section{REFERENCES}

1. Big medical encyclopedia: 11 volumes / Ch. ed. M. Kovalev. V. 11. Moscow : The Soviet Encyclopedia, 1979. P. 320

2. WHO guidelines on the transplantation of human cells, tissues and organs, approved at the 63rd session of the World Conservation Assembly Health May 21, 2010, resolution WHA 63.22. URL: https://www.who.int/transplantation/Guiding_PrinciplesTransplantation_ WHA63.22en.pdf?ua $=1$

3. On transplantation of organs and other anatomical materials to man : Law of Ukraine of July 16, 1999. Voice of Ukraine. 08/17/1999 (in Ukraine).

4. On the Application of Transplantation of Anatomical Materials to Man : The Law of Ukraine, dated May 17, 2018 № 2427-VIII. Voice of Ukraine. 2018. № 115 (in Ukraine).

5. The Additional Protocol to the Convention on Human Rights and Biomedicine concerning the Transplantation of Human Organs and Tissues was adopted in Strasbourg, on January 24, 2002. URL: https://zakon.rada.gov.ua/laws/show/994_684 (in Ukraine).

6. Korenga Yu. Legal aspects of legal relations in the field of transplantation of human organs and tissues. Historical and legal journal. 2015. № 2. P. 97-101. URL: http://nbuv.gov.ua/UJRN/ipch_2015_2_20.

7. The Criminal Code of Ukraine of April 5, 2001, № 2341-III. Vedomosti Verkhovna Rada of Ukraine. 2001. № № 25-26. Article 131 (in Ukraine).

8. The Constitution of Ukraine dated June 28, 1996. Vedomosti Verkhovna Rada of Ukraine. 1996. № 30. Art. 141 (in Ukraine).

9. Maleina M. Man and medicine in modern law. Educational and practical guide. Moscow, 1995. P. 76-92.

10. Bryukhovetskaya M. Civil law regulation of posthumous donation in Ukraine : dis. ... of cand. legal sciences: 12.00.03. Kiev, 2017. 230 p.

11. Pelagesha A. Administrative and legal support of transplantation of organs and other anatomical materials to a person in Ukraine : dis. ... of cand. legal sciences: 12.00.07. Kiev, 2011. $199 \mathrm{p}$.

12. Mishchuk I. Improving the Administrative and Legal Regulation of Human Organ and Tissue Transplantation Based on Foreign Experience : author's abstract. dis. ... of cand. legal sciences: 12.00.07. Kiev, 2014. $21 \mathrm{p}$.

13. Anikina G. Civil law regulation of relations connected with the death of a person : author's abstract. dis. ... of cand. legal sciences: 12.00.03. Kiev, 2014. 16 p.

14. On the establishment of diagnostic criteria for brain death and the procedure for ascertaining the moment of death of a person: Order of the Ministry of Health of September 23, 2013 № 821 / Ministry of Health of Ukraine. URL: https://zakon.rada.gov.ua/laws/show/z1757-13\#n22 (in Ukraine).

УДК 342.729

DOIhttps://doi.org/10.32782/2524-0374/2019-4/38

\section{ОСОБЛИВОСТІ РЕАЛІЗАЦІЇ ПРАВА НА СВОБОДУ МИРНИХ ЗІБРАНЬ В УМОВАХ ПРОВЕДЕННЯ ОПЕРАЦІЇ ОБ'Є ДНАНИХ СИЛ}

\section{SPECIFICS OF THE RIGHT REALIZATION TO FREEDOM OF PEACEFUL ASSEMBLY IN THE CONTEXT OF A UNITED FORCE OPERATION}

Онищенко С.М., провідний науковий співробітник науково-організаційного відділу Державний науково-дослідний інститут МВС Украӥни здобувач Державний науково-дослідний інститут МВС Украӥни

\footnotetext{
У статті здійснено спробу аналізу особливості реалізації права на свободу мирних зібрань в умовах проведення операції Об'єднаних сил. Розглянуто положення законодавства України, що регламентують порядок проведення мирних зібрань в умовах «звичайного» правового режиму (мітинги забороняє лише суд), правового режиму воєнного стану (мітинги забороняє військове командування та військові адміністрації, згідно зі ст. 8 чинного Закону «Про правовий режим воєнного стану») та правового режиму надзвичайного стану (мітинги забороняє суд або інший орган, який може бути визначений у законодавстві). Наголошено на тому, що проблеми захисту прав і свобод людини, зокрема й права на мирні зібрання, особливо загострились в умовах тимчасової окупації частини території України та військової агресії Російської Федерації в окремих районах Донецької і Луганської областей, що призвело до зростання ризиків непропорційного обмеження прав і свобод.

Спираючись на наведену хронологічну послідовність етапів протидії військовій агресії Російської Федерації в межах Антитерористичної операції, операції Об'єднаних сил та в проміжок упровадження воєнного стану, проаналізовано особливості реалізації права на мирні зібрання на «прифронтовій» території. На практичних прикладах висвітлено суперечність між об'єктивною потребою врегулювання порядку проведення мирних зібрань у «прифронтових» районах і браком необхідних правових механізмів, що призводить до необґрунтованого обмеження права на мирні зібрання, зокрема, фактичного встановлення дозвільного порядку проведення таких зібрань. Отримані
} 